Матеріали Всеукраїнської науково-практичної конференції «Актуальні питання діагностики, лікування, раціональної фармакотерапії, диспансеризації та реабілітації в практиці сімейного лікаря»

$\mathrm{DOI}$

\title{
ВЗАЕМОЗВ'ЯЗОК ТРИВОЖНО-ДЕПРЕСИВНИХ РОЗЛАДІВ ЗІ СТУПЕНЕМ КОМПЕНСАЦІЇ ЦД 2 ТИПУ У ХВОРИХ НА ІХС
}

๑А. І. Мельник, О. О. Зеленіна

Запорізький державний медичний університет

Мета: вивчити взаємозв'язок тривожнодепресивних розладів (ТДР) зі ступенем компенсації ЦД у хворих на IXC.

Матеріал та методи дослідження. Обстежений 41 хворий з IXС: стабільною стенокардією напруги II-III ФК і супутнім ЦД 2 типу (середній вік $(69,85 \pm 0,99)$ р.): І гр. - 19 хворих з компенсацією ЦД (рівень НbA1c<6,5 \%), II гр. - 22 пацієнти з субкомпенсацією ЦД (рівень НbA1c $26,5 \%$ ). Всім хворим проводили обстеження згідно з Національними стандартами (Наказ МО3 України № 436 від 03.07.2006 р.). ТДР діагностували за допомогою шкали тривоги і депресії HADS, якість життя - Ciетлівського опитувальника (SAQ).

Результати дослідження: ТДР спостерігали у 67 \% хворих I гр. і у 45,83\% II гр. Пацієнти I гр., порівняно з хворими II гр., мали високий рівень три- воги $((7,38 \pm 1,30)$ проти $(6,6 \pm 1,17)$; $p<0,05)$ і депреciї $((6,5 \pm 1,13)$ проти $(5,73 \pm 1,04) ; p<0,05)$ за шкалою HADS. У хворих I гр. спостерігали тенденцію до збільшення САД, збільшення ТГ на 52 \%, 3Х на $19 \%$ $(p<0,05)$, тенденцію до зниження ХС-лПВщ. Встановлено кореляційний взаємозв'язок між HbA1c і сумарним рівнем тривоги і депресії ( $r=+0,34$; $p<0,05)$, загальним XC ( $r=+0,55 ; p<0,05)$, ступенем обмеження фізичної активності $(r=-0,76 ; p<0,05)$ i задоволеністю лікуванням $(r=-0,54 ; p<0,05)$ за даними SAQ.

Висновки: У пацієнтів з ЦД 2 типу та рівнем HbA1c $\geq 6,5 \%$ спостерігається збільшення частоти і ступеня вираженості ТДР за шкалою HADS, які асоціюються з більш вираженими порушеннями ліпідного спектра і зниженням якості життя за даними SAQ. 